\title{
Landslide susceptibility in Rasuwa District of central Nepal after the 2015 Gorkha Earthquake
}

\author{
*Badal Pokharel ${ }^{1,2}$ and Prem Bahadur Thapa ${ }^{1}$ \\ ${ }^{I}$ Department of Geology, Tri-Chandra Multiple Campus, Tribhuvan University, Kathmandu, Nepal \\ ${ }^{2}$ Himalayan Risk Research Institute, Bhaktapur, Nepal \\ *Corresponding author: badal.pokharel2@gmail.com
}

\begin{abstract}
The 2015 Gorkha Earthquake (7.8 Mw) triggered several landslides in central Nepal with major damages in 14 districts. Among them, the Rasuwa district at the north of Kathmandu Valley faced severe landslides due to rugged topography, complex geology and improper landuse development. The landslides had blocked the Pasang Lhamu Highway and dammed the Trishuli River at many places. A total of 1416 landslide locations were detected in the district from high resolution satellite images in Google Earth. In this study, landslide susceptibility was modeled in the Rasuwa District by considering slope, aspect, elevation, geology, peak ground acceleration (PGA), landuse, drainage proximity and thrust proximity as the predictive factors for landslide occurrences. The landslide inventory was split into $70 \%$ and $30 \%$ portions as the training dataset and testing dataset respectively. The results from modified frequency ratio (FR) suggest that effect of geology with prediction rate 2.52 is the highest among all factors and is followed by elevation (2.38) and drainage proximity (2.12). The results were verified using area under curve (AUC) and the prediction rate was found to be $79.14 \%$. The computed landslide susceptibility map is helpful for landuse planning and landslide risk reduction measure in the Rasuwa District.
\end{abstract}

Keywords: Landslide, Frequency ratio, Susceptibility, Validation, Rasuwa District

Paper Received: 28 Dec 2018

Paper Accepted: 30 May 2019

\section{INTRODUCTION}

Complex geological structures, rugged topography and extreme rainfall events lead to high landslides activity in the Rasuwa District of central Nepal (Acharya et al. 2006). The April 25, 2015 Gorkha Earthquake with 7.8 Mw magnitude struck with its epicenter at Barpark, 50 kilometers eastwards of the district. The mainshock was followed by 553 aftershocks $(\mathrm{Ml}>4.0)$ within the first 45 days (Adhikari et. al., 2015) and a major aftershock of 7.3 Mw also occurred on May 12, 2015 in between. The mainshock and aftershocks triggered about 25000 landslides in this region mainly occurring in a wide swath between the main shock and the major aftershock (Gnyawali and Adhikari, 2017; Roback et. al., 2017). Rasuwa, Dhading, Nuwakot, Sindhupalchowk and Gorkha had been the most affected districts with highest damage in Rasuwa (Regmi et al., 2016).

Landslide susceptibility assessment (LSA) measures the spatial probability of landslide occurrences based on different slope failure conditioning factors (Guzzetti, 2005). It aids planners and decision makers to prevent and mitigate landslide hazard (Chawala et. al., 2018). The methods of LSA are of three basic types: 1. Knowledge-driven, 2. Data-driven and 3. Physically based (Corominas et al., 2014). Knowledge-driven methods assess the susceptibility by expert weighting of conditioning factors. Data-driven methods assess by statistical comparisons of the conditioning factors. In it, future landslide occurrence is assumed to be governed by the conditioning factors, that will occur under the same conditions as the past landslides (Lee and Pradhan, 2006). Physically based models use geotechnical slope failure processes models. Data driven techniques are the most popular method of LSA (Corominas et al., 2014) because of their rigorous scientific approach and their primary data layers are comparatively easily available. Frequency ratio (FR) is a data driven quantitative method that can perform Bivariate Statistical Analysis (Lee and Dan 2005; Pham et al. 2015). In FR method, the spatial relationship between landslide and its causative factor is analyzed and the method assesses the impact of the classes of each causative factor due to landslide occurrence (Lee and Pradhan, 2006; Lee and Sambath, 2006).

The 2015 Gorkha earthquake provided an opportunity to assess the susceptibility of this landscape for landslides triggered by the earthquake. Acharya et al. (2006) made a case study to access landslide hazard in Raswua District for rainfall triggered landslides. Meena (2017) developed principles for designing sustainable landslide inventory in Nepal. Xu et al. (2017) performed the LSA of earthquake triggered landslides in two highway corridors connecting China and Nepal NorthSouth oriented, while one of them (Pasang Lhamu Highway) passes through the Rasuwa district. Regmi et.al. (2016) performed the LSA of the whole region affected by the Gorkha earthquake while detailed assessment based on comprehensive landslide 


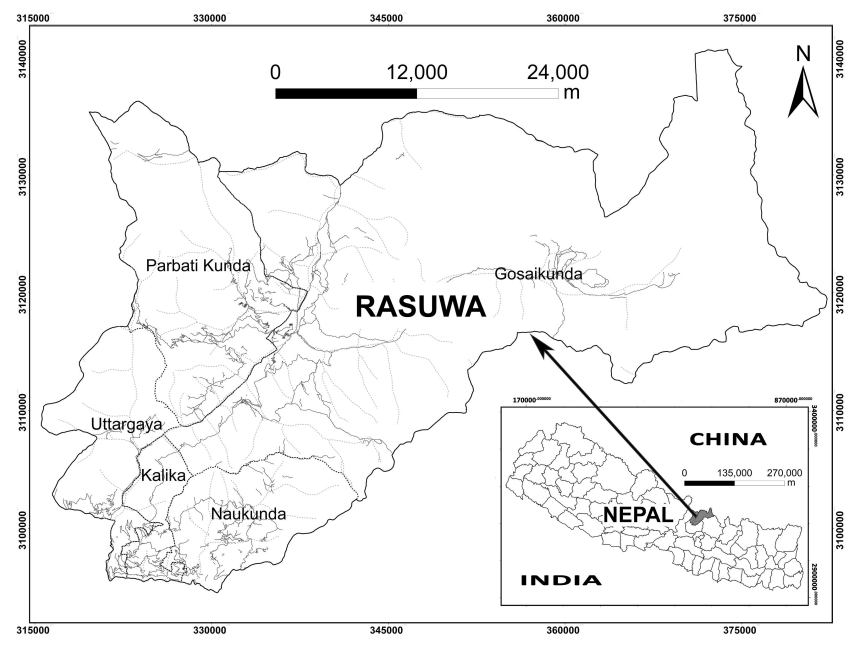

Fig. 1: Location Map of Study Area

inventories and geo-political boundaries has not been performed.

In this study, earthquake triggered landslide susceptibility assessment of the Rasuwa District is performed based on eight landslide conditioning factors and using the modified frequency ratio method. Comparative evaluation of the conditioning factors is further performed to determine the dominant factors to consider for the district.

\section{STUDY AREA}

The study area is the Rasuwa District in Province No. 3 which lies north of Kathmandu Valley (Fig. 1). There are five rural municipalities in Rasuwa namely Kalika, Gosaikunda, Naukunda, Parbatikunda and Uttargaya. The district covers an area of about $1544 \mathrm{sq}$. $\mathrm{km}$. The altitude ranges from 596 to $7216 \mathrm{~m}$. This area has a typical monsoon climate characterized by high and intense rainfall from June to September (Acharya et al., 2006). More than $40 \%$ of the land is barren, $25 \%$ is forest and $9 \%$ is cultivated. Trishuli River is the major river draining the study area southwards. Besides Trisuli River, there are many tributaries and sub-tributaries distributed in the study area and overall drainage pattern is dendritic. Langtang National Park is located in northern part of Raswua district. The study area is connected to Kathmandu by Pasang Lhamu Highway. The major road from Galchi to Rasuwagadhi connects Rasuwa with Tibet. There are many minor roads and trails connecting the rural municipalities within the district. The roadways in Rasuwa were severely affected by co-seismic landslides.

About 19 aftershocks were recorded until May 12, 2015 by National Seismological Centre (NSC) in Rasuwa and most of them were in the range of 4.0 to 5.0 ML. The significant settlements were impacted by the landslides in Rasuwa are Ramche, Dandagaun, Laharepauwa, Dhaibung, Yarsa, Dhunche and Haku. Nearly 1135 households were affected severely, 3 school buildings were damaged and 5 school buildings were affected in the Rasuwa District due to the landslides triggered by major shock on April 25, 2015 (Shrestha et al., 2016). The earthquake induced landslide avalanche in Lantang Valley is the largest landslide triggered by Gorkha Earthquake (Collins and Jibson, 2015; Kargel et al., 2016) that buried and damaged several villages and killed more than 350 people (Kargel et al., 2016). Landslides also dammed the rivers at several places and caused major damages to hydropower project at Mailung Khola (Shrestha et al. 2016). About 89 co-seismic landslides were delineated along Pasang Lhamu Highway that blocked the key economic route between China and Nepal (Xu et al., 2017).

\section{Geology of the study area}

Geologically, Rasuwa comprises rocks of Midland Group and the Recent deposits. The Mid-land Group consist of the Lakharpata Subgroup and the Dailekh Subgroup belongs to the Lesser Himalayan rocks (Dhital, 2015). The Dailekh Subgroup includes the Kushma Formation consisting medium to finegrained, green to white quartzites, the Seti Formation with gritty phyllite and metasandstone, the Naudanada Formation consisting fine to medium-grained white quartzites and the Ghanpokhara Formation with black carbonaceous phyllites, slates and shale with white limestones (Dhital, 2015). Similarly, the Lakharpata Subgroup includes the Galyang Formation comprising black slates, the Sangram Formation rich in black laminated shales with limestone and quartz interbeds, the Syangja Formation with calcareous quartzites and dolomitic limestones, and the Lakharpata Formation with limestones, dolomites, containing stromatolites, with thin intercalation of shale (Dhital, 2015). The Recent Deposit consists of alluvium, boulder, gravels, sands and clays. The major thrust fault in the area is the Main Central Thrust (MCT).

\section{DATA}

The data layers and their source used in this study are given in Table 1. Slope, aspect, elevation, geology, landuse, PGA, drainage proximity and thrust proximity are considered as the conditioning factors for LSA (Fig. 2).

Slope is the fundamental parameter in slope stability analysis (Lee and Min, 2001). Due to the direct relationship of slope with the landslide, it is always used as a main causative factor in landslide susceptibility studies (Dai et al., 2001; Lee, 2005; Nefeslioglu et al., 2008). Slope aspect has influence on co-seismic landslides because with different slope aspects, the propagating direction of seismic waves varies (Xu et al. 2017). The land sliding is further controlled by different parameters related to slope aspect like drying winds, sunlight, rainfall and discontinuities (Dai et al., 2001; Komac, 2006). Elevation has no direct relation with landslides but some researches show the occurrence of landslides at higher elevations (Ercanoglu and Gokceoglu, 2004). Due to the varying physical properties of the lithological units which cause differences in their permeability and strength, geological parameters have great influence in the occurrence of landslides (Pradhan and Lee, 2010). Landuse is another key parameter that influences the landslide occurrences. 
Table 1: Data type and sources

\begin{tabular}{|c|c|c|}
\hline Classification & GIS data type & Source \\
\hline SPOT 5 satellite Image (After August, 2015) & $1.5 \mathrm{~m}$ - pansharpened, Grid & $\begin{array}{l}\text { Provided by National Reconstruction Authority } \\
\text { (NRA) }\end{array}$ \\
\hline DEM & Grid $(25 \mathrm{~m} \times 25 \mathrm{~m})$ & Topographical Survey Department \\
\hline Landslide inventory & Polygon coverage & Prepared in GIS by manual digitization \\
\hline Geological Map & Polygon coverage & $\begin{array}{l}\text { Raw data provided by Department of Mines and } \\
\text { Geology (DMG), Digitized in GIS }\end{array}$ \\
\hline Landuse Map & Polygon coverage & Department of Survey \\
\hline Drainage Map & Line and polygon coverage & $\begin{array}{l}\text { Extracted from topographic map using digitization } \\
\text { technique in GIS }\end{array}$ \\
\hline Thrust Map & Line and polygon coverage & $\begin{array}{l}\text { Extracted from Geological Map published by DMG } \\
\text { in } 2011\end{array}$ \\
\hline Peak Ground Acceleration (PGA) Map & Polygon Coverage & USGS \\
\hline
\end{tabular}

Franks (1999) based on study of natural terrain concluded that sparsely vegetated slopes are more susceptible to failure. PGA is considered as a seismic parameter in this study. Co-seismic landslides occur due to the strong ground shaking and the strength of ground shaking is given by maximum acceleration (Tsapanos, 2003). More landslides are generally occurred around the vicinity of thrust due to fracturing of rocks. Drainage patterns have effect on the stability by eroding the slopes or by saturating the lower part of slope materials (Gokceogly and Aksoy, 1996; Dai et al., 2001; Saha et al., 2002; Yalcin, 2005).

\section{METHODOLOGY}

The landslide inventory was manually digitized by comparing with pre-and-post- earthquake satellite images. The, it was divided into $70 \%$ training dataset and 30\% testing dataset based on random selection (Fig. 3). All the data layers were imported in a GIS environment for the analysis and reclassified using commonly adopted classification breaks. A flowchart of the overall process used in this study is presented in (Fig. 4).

Frequency ratio is defined as the ratio of landslide occurrence in a class to the total area of that class for a landslide conditioning factor. Mathematically,

$$
\left.\mathrm{FR}=\left(\mathrm{N}_{\mathrm{i}} \mathrm{p} / \mathrm{N}\right) / \mathrm{N}_{\mathrm{i}} \mathrm{p} / \mathrm{N}^{1}\right)
$$

where, $\mathrm{N}_{\mathrm{i}} \mathrm{p}$ is the number of pixels in each landslide conditioning factor class, $\mathrm{N}$ is the number of all pixels in the total study area. $\mathrm{N}_{\mathrm{i}}$ lp is the number of landslide pixels in each landslide conditioning factor class, $\mathrm{N}^{1}$ is the number of all landslide pixels in the total study area.

To determine the relative importance of each spatial factor within the training dataset, prediction rate (PR) for every conditioning factor was derived based on their degree of spatial association with the landslides (Gosh et al. 2011).

$$
\operatorname{Pr}=|\mathrm{SAmax}-\mathrm{Samin}| /|\mathrm{SAmax}-\mathrm{SAmin}| \min \ldots \ldots .
$$

where, SAmax and SAmin are the maximum RFs among classes within a factor respectively.

Finally, landslide susceptibility map is prepared using the formula:

$$
\mathrm{LSM}=\operatorname{Sumi}\left(\operatorname{Pr}_{\mathrm{i}} \times \mathrm{Fr}_{\mathrm{i}}\right) .
$$

where, $\mathrm{Fr}_{\mathrm{i}}$ is the rating of each factor's type and $\mathrm{Pr}_{\mathrm{i}}$ is the multiplier (rating) for each factor.

\section{RESULTS}

Slope angle, slope aspect, elevation, geology, landuse, drainage proximity and thrust proximity are quasi-static variables whereas PGA is dynamic variable. Using Eq. 1, FR for each class is calculated and PR is obtained using Eq. 2. The relative frequency (RF) is also calculated. The result is presented in .

The greater the value of FR means stronger relationship between conditioning factor and landslides. Slope ranging between $15^{\circ}$ to $30^{\circ}$ and $30^{\circ}$ to $40^{\circ}$ have FR of 1.14 and 1.99 respectively. This means most of the landslides in study area are likely to be concentrated within these slopes. Higher probability of landslides was found in south-east facing slope which had FR of 2.42. In case of elevation, landslides are abundant in range of 596-1613 $\mathrm{m}, 1613-2256 \mathrm{~m}$ and 2256-28232 m with FR 6.64, 3.03 and 1.10 respectively. Landslide distribution has decreased with increase in the elevation. The value of FR for the Ulleri Formation is 13.54 which imply this formation is very susceptible to the landslides. The Seti Formation, the Recent Deposits and the Ghan Pokhara Formation also have FR greater than 1 showing strong relation to landslide occurrence.

Bush and grassland with FR 2.42 and 2.09 respectively bear the high probabilities of landslide occurrence in case of land use. In case of PGA, the range $0.56-0.68 \mathrm{~g}$ has the highest FR of 2.76 indicating the higher chances of landslides. The landslide occurrence probability is highest for thrust proximity of range 0-3.1 km with FR of 2.49 whereas for drainage $0-0.3$ $\mathrm{km}$ range with FR 2.39 seems to suffer from landslides. For both cases, the probability is low with increase in proximity.

Landslide susceptibility map is prepared using Eq. 3. The factor maps are first reclassified using Relative Frequency $(\mathrm{RF})$ and is process using Prediction Rate (PR) as the rating 

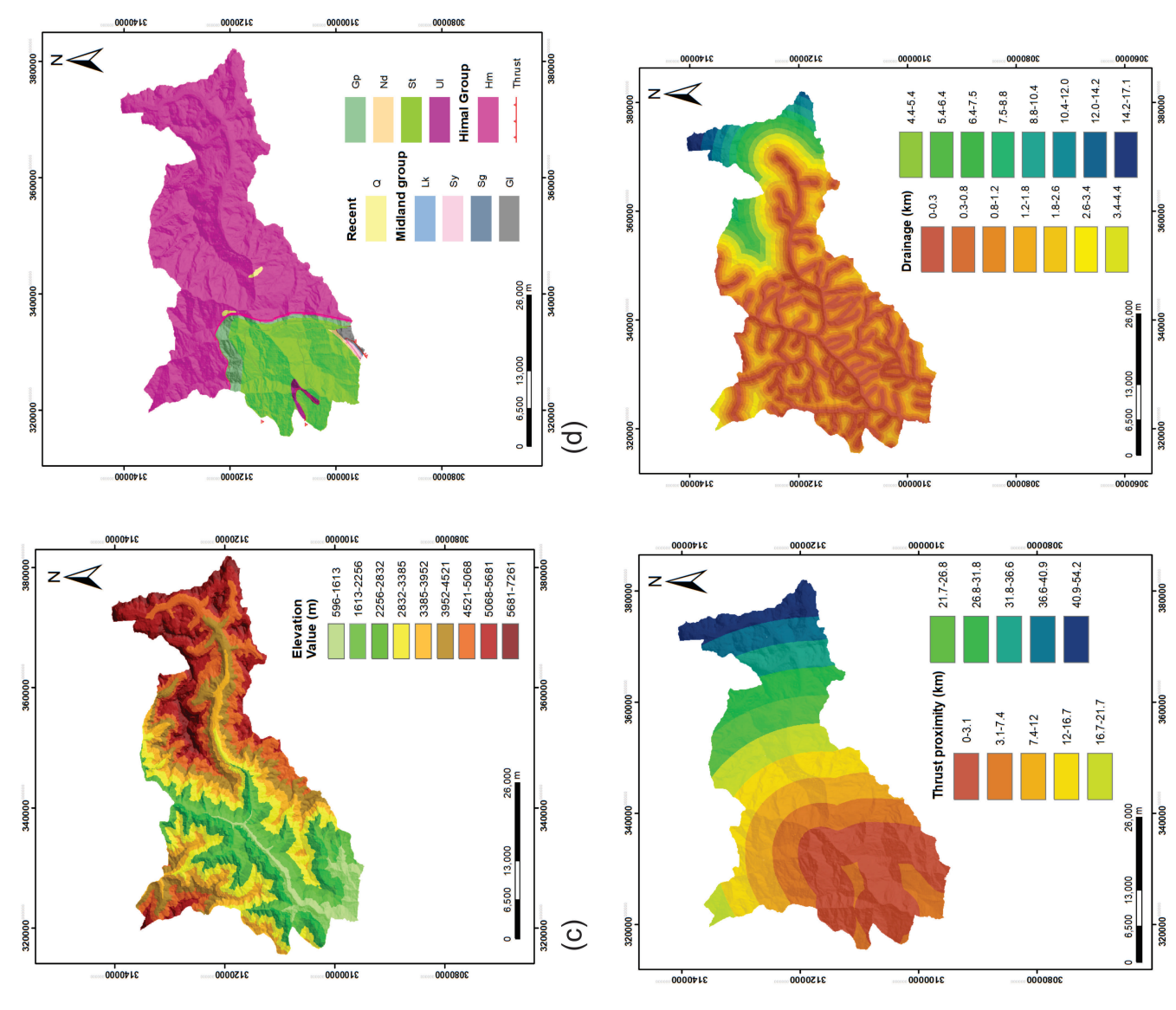

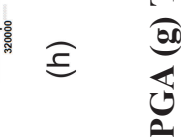

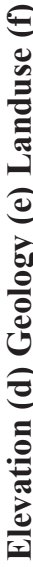
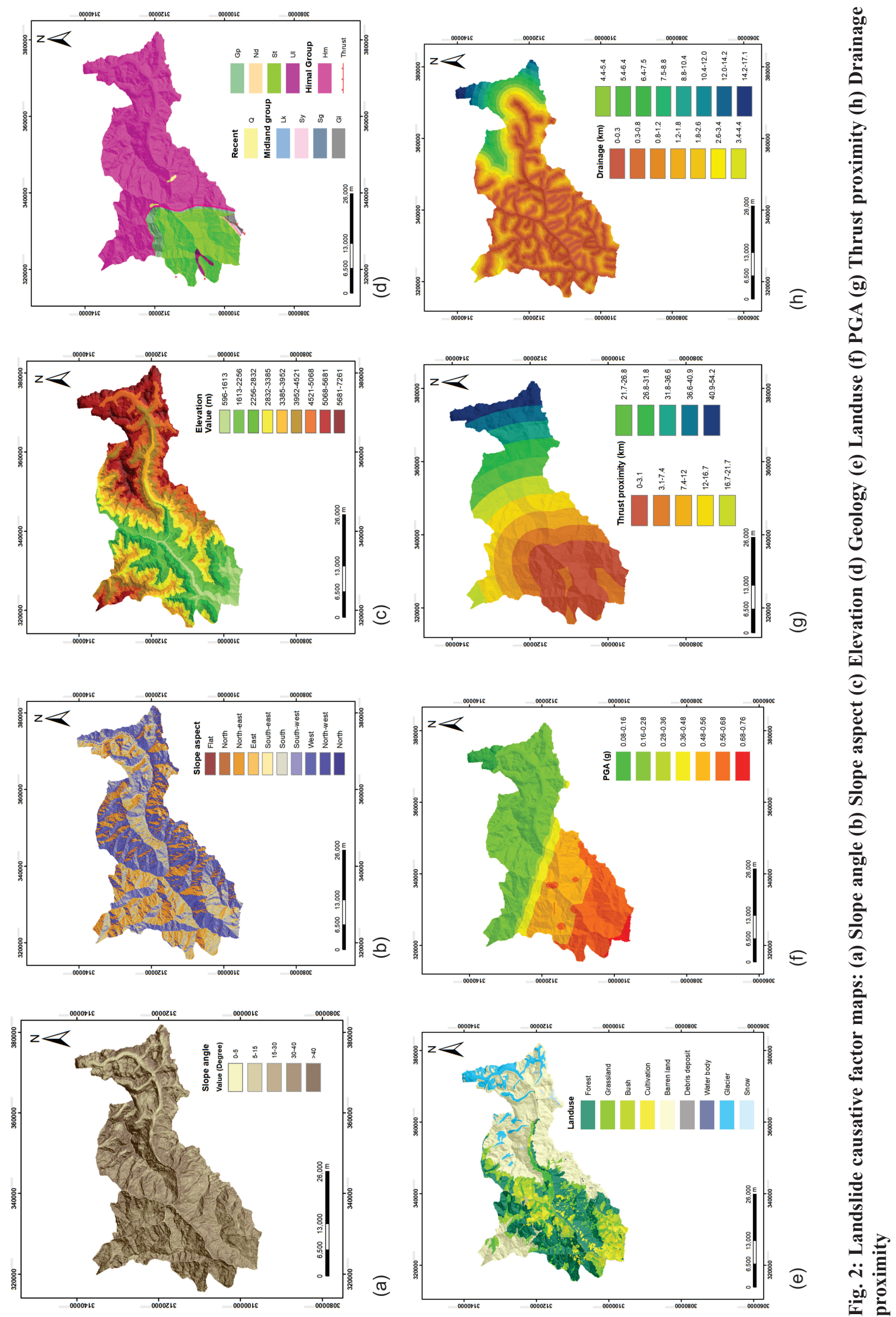
Landslide susceptibility in Rasuwa District of central Nepal after the 2015 Gorkha Earthquake

Table 2: FR and PR for each classes of landslide conditioning factor

\begin{tabular}{|c|c|c|c|c|c|c|c|c|c|c|}
\hline Factors & Class & Landslide \% & Domain \% & FR & $\mathrm{RF}$ & Min RF & Max RF & $(\operatorname{Max}-\operatorname{Min})(\mathrm{A})$ & Min. of A (B) & $\mathrm{PR}=\mathrm{A} / \mathrm{B}$ \\
\hline Slope angle & $0-5^{\circ}$ & 0.27 & 1.53 & 0.18 & 0.04 & 0.04 & 0.49 & 0.44 & 0.24 & 1.87 \\
\hline \multirow[t]{5}{*}{ (degree) } & $5^{\circ}-15^{\circ}$ & 2.74 & 8.97 & 0.31 & 0.07 & & & & & \\
\hline & $15^{\circ}-30^{\circ}$ & 18.06 & 37.22 & 0.49 & 0.12 & & & & & \\
\hline & $30^{\circ}-40^{\circ}$ & 33.37 & 29.37 & 1.14 & 0.28 & & & & & \\
\hline & $>40^{\circ}$ & 45.55 & 22.90 & 1.99 & 0.49 & & & & & \\
\hline & Total & 100.00 & 100.00 & 4.09 & 1.00 & & & & & \\
\hline \multirow[t]{11}{*}{ Slope aspect } & Flat & 0.06 & 0.20 & 0.31 & 0.03 & 0.03 & 0.27 & 0.24 & & 1.00 \\
\hline & $\mathrm{N}$ & 2.17 & 6.56 & 0.33 & 0.04 & & & & & \\
\hline & $\mathrm{NE}$ & 4.04 & 11.44 & 0.35 & 0.04 & & & & & \\
\hline & $\mathrm{E}$ & 15.16 & 10.72 & 1.41 & 0.16 & & & & & \\
\hline & SE & 28.31 & 11.68 & 2.42 & 0.27 & & & & & \\
\hline & $\mathrm{S}$ & 17.70 & 12.71 & 1.39 & 0.16 & & & & & \\
\hline & SW & 11.25 & 12.55 & 0.90 & 0.10 & & & & & \\
\hline & W & 7.05 & 13.68 & 0.52 & 0.06 & & & & & \\
\hline & NW & 10.76 & 13.55 & 0.79 & 0.09 & & & & & \\
\hline & $\mathrm{N}$ & 3.50 & 6.91 & 0.51 & 0.06 & & & & & \\
\hline & Total & 100.00 & 100.00 & 8.93 & 1.00 & & & & & \\
\hline Elevation (m) & $596-1613$ & 40.40 & 6.08 & 6.64 & 0.56 & 0.00 & 0.56 & 0.56 & & 2.38 \\
\hline & $1613-2256$ & 32.47 & 10.72 & 3.03 & 0.26 & & & & & \\
\hline & $2256-2832$ & 13.66 & 12.40 & 1.10 & 0.09 & & & & & \\
\hline & $2832-3385$ & 8.80 & 14.17 & 0.62 & 0.05 & & & & & \\
\hline & $3385-3952$ & 3.44 & 11.60 & 0.30 & 0.03 & & & & & \\
\hline & $3952-4521$ & 0.72 & 12.05 & 0.06 & 0.01 & & & & & \\
\hline & $4521-5068$ & 0.45 & 14.48 & 0.03 & 0.00 & & & & & \\
\hline & $5068-5681$ & 0.06 & 12.91 & 0.00 & 0.00 & & & & & \\
\hline & $5681-7216$ & 0.00 & 5.59 & 0.00 & 0.00 & & & & & \\
\hline & Total & 100.00 & 100.00 & 11.79 & 1.00 & & & & & \\
\hline Geology & Q & 0.66 & 0.25 & 2.67 & 0.12 & 0.00 & 0.60 & 0.60 & & 2.52 \\
\hline & Lk & 0.06 & 0.03 & 2.19 & 0.10 & & & & & \\
\hline & Sy & 0.00 & 0.22 & 0.00 & 0.00 & & & & & \\
\hline & $\mathrm{Sg}$ & 0.00 & 0.004 & 0.00 & 0.00 & & & & & \\
\hline & $\mathrm{Gl}$ & 0.06 & 0.44 & 0.14 & 0.01 & & & & & \\
\hline & Gp & 3.59 & 3.08 & 1.16 & 0.05 & & & & & \\
\hline & $\mathrm{Nd}$ & 0.03 & 0.20 & 0.15 & 0.01 & & & & & \\
\hline & St & 55.98 & 23.17 & 2.42 & 0.11 & & & & & \\
\hline & Ul & 8.62 & 0.64 & 13.54 & 0.60 & & & & & \\
\hline & $\mathrm{Hm}$ & 30.99 & 71.98 & 0.43 & 0.02 & & & & & \\
\hline & Total & 100.00 & 100.00 & 22.70 & 1.00 & & & & & \\
\hline Landuse & Barren land & 3.04 & 40.42 & 0.08 & 0.01 & 0.00 & 0.25 & 0.25 & & 1.03 \\
\hline & Glacier & 0.51 & 6.58 & 0.08 & 0.01 & & & & & \\
\hline & Water body & 0.30 & 0.22 & 1.36 & 0.13 & & & & & \\
\hline & Snow & 0.00 & 0.44 & 0.00 & 0.00 & & & & & \\
\hline & Debris deposit & 0.84 & 0.50 & 1.70 & 0.16 & & & & & \\
\hline & Grassland & 24.33 & 11.67 & 2.09 & 0.19 & & & & & \\
\hline & Cultivation & 8.35 & 8.21 & 1.02 & 0.09 & & & & & \\
\hline & Forest & 44.89 & 25.24 & 1.78 & 0.17 & & & & & \\
\hline & Bush & 17.73 & 6.73 & 2.63 & 0.25 & & & & & \\
\hline & Total & 100.00 & 100.00 & 10.73 & 1.00 & & & & & \\
\hline PGA (g) & $0.08-0.16$ & 0.00 & 2.72 & 0.00 & 0.00 & 0.00 & 0.42 & 0.42 & & 1.76 \\
\hline & $0.16-0.28$ & 13.75 & 46.99 & 0.29 & 0.04 & & & & & \\
\hline & $0.28-0.36$ & 1.63 & 2.45 & 0.66 & 0.10 & & & & & \\
\hline & $0.36-0.48$ & 5.52 & 5.22 & 1.06 & 0.16 & & & & & \\
\hline & $0.48-0.56$ & 19.17 & 20.10 & 0.95 & 0.14 & & & & & \\
\hline & $0.56-0.68$ & 58.88 & 21.31 & 2.76 & 0.42 & & & & & \\
\hline & $0.68-0.76$ & 1.06 & 1.21 & 0.88 & 0.13 & & & & & \\
\hline & Total & 100.00 & 100.00 & 6.61 & 1.00 & & & & & \\
\hline Thrust (km) & $0-3.1$ & 60.96 & 24.47 & 2.49 & 0.44 & 0.00 & 0.44 & 0.44 & & 1.84 \\
\hline & $3.1-7.4$ & 15.19 & 14.78 & 1.03 & 0.18 & & & & & \\
\hline & 7.4-12 & 12.84 & 12.18 & 1.05 & 0.18 & & & & & \\
\hline & $12-16.7$ & 9.62 & 10.70 & 0.90 & 0.16 & & & & & \\
\hline & $16.7-21.7$ & 0.06 & 8.53 & 0.01 & 0.00 & & & & & \\
\hline & $21.7-26.8$ & 0.00 & 7.27 & 0.00 & 0.00 & & & & & \\
\hline & $26.8-31.8$ & 0.63 & 6.30 & 0.10 & 0.02 & & & & & \\
\hline & $31.8-36.6$ & 0.18 & 4.62 & 0.04 & 0.01 & & & & & \\
\hline & $36.6-40.9$ & 0.00 & 5.41 & 0.00 & 0.00 & & & & & \\
\hline & $40.9-54.2$ & 0.51 & 5.75 & 0.09 & 0.02 & & & & & \\
\hline & Total & 100.00 & 100.00 & 5.71 & 1.00 & & & & & \\
\hline Drainage & $0-0.3$ & 57.37 & 24.02 & 2.39 & 0.50 & 0.00 & 0.50 & 0.50 & & 2.12 \\
\hline$(\mathrm{km})$ & $0.3-0.8$ & 35.30 & 22.81 & 1.55 & 0.33 & & & & & \\
\hline & $0.8-1.2$ & 4.46 & 16.92 & 0.26 & 0.06 & & & & & \\
\hline & $1.2-1.8$ & 2.11 & 10.35 & 0.20 & 0.04 & & & & & \\
\hline & $1.8-2.6$ & 0.24 & 5.34 & 0.05 & 0.01 & & & & & \\
\hline & $2.6-3.4$ & 0.00 & 3.78 & 0.00 & 0.00 & & & & & \\
\hline & $3.4-4.4$ & 0.00 & 3.17 & 0.00 & 0.00 & & & & & \\
\hline & $4.4-5.4$ & 0.00 & 2.94 & 0.00 & 0.00 & & & & & \\
\hline & 5.46 .4 & 0.00 & 2.74 & 0.00 & 0.00 & & & & & \\
\hline & $6.4-7.5$ & 0.00 & 2.38 & 0.00 & 0.00 & & & & & \\
\hline & $7.5-8.8$ & 0.51 & 1.68 & 0.31 & 0.06 & & & & & \\
\hline & $8.8-10.4$ & 0.00 & 1.38 & 0.00 & 0.00 & & & & & \\
\hline & $10.4-12.0$ & 0.00 & 1.16 & 0.00 & 0.00 & & & & & \\
\hline & $12.0-14.2$ & 0.00 & 0.77 & 0.00 & 0.00 & & & & & \\
\hline & $14.2-17.1$ & 0.00 & 0.56 & 0.00 & 0.00 & & & & & \\
\hline & Total & 100.00 & 100.00 & 4.75 & 1.00 & & & & & \\
\hline
\end{tabular}




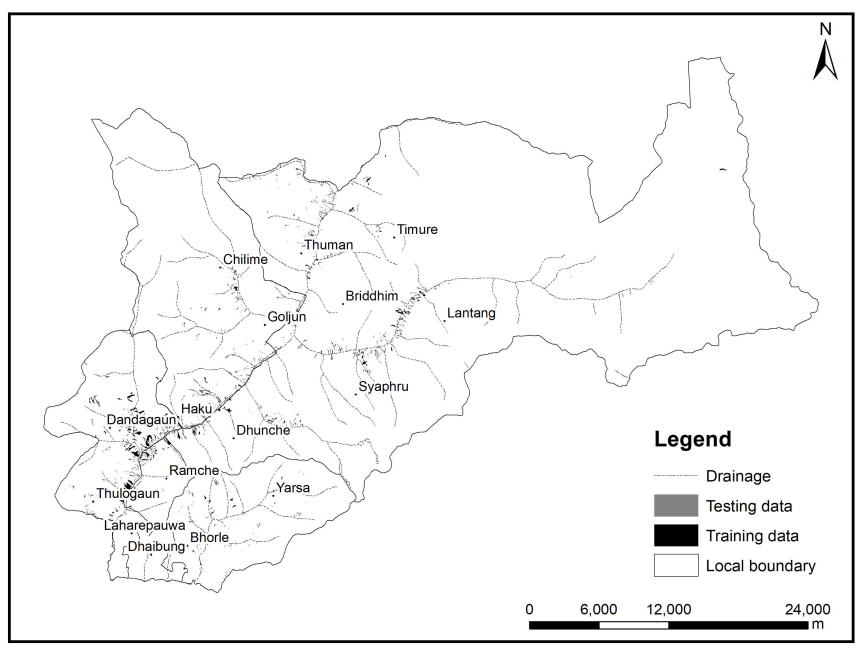

Fig. 3: Training and testing data for landslide inventory in study area

(multiplier). The equation for this study is given as: $\mathrm{LSM}=(1.87 \times$ Slope angle $)+(1 \times$ Slope aspect $)+$ $(2.38 \times$ elevation $)+(2.52 \times$ geology $)+$ $(1.03 \times$ landuse $)+(1.76 \times \mathrm{PGA})+(1.84 \times$ thrust proximity $)$ $+(2.12 \times$ drainage proximity $) ..$. Eq. $(4)$
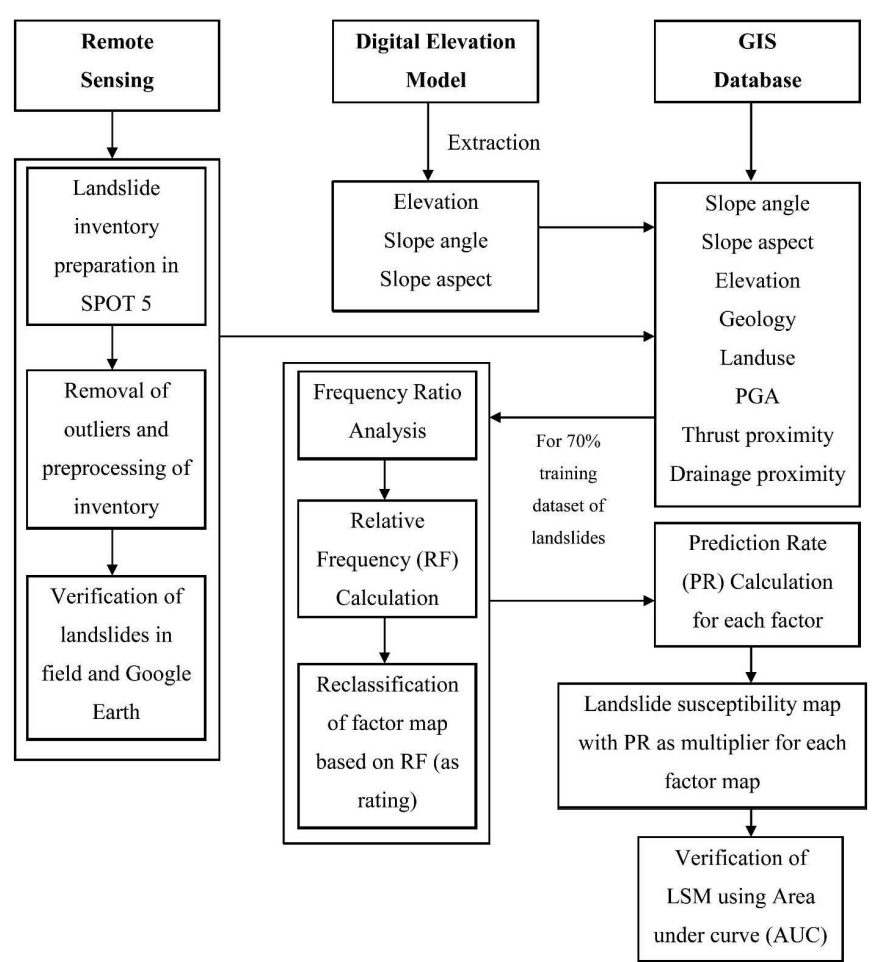

Fig. 4: Procedure adopted for preparing LSM using modified FR method.

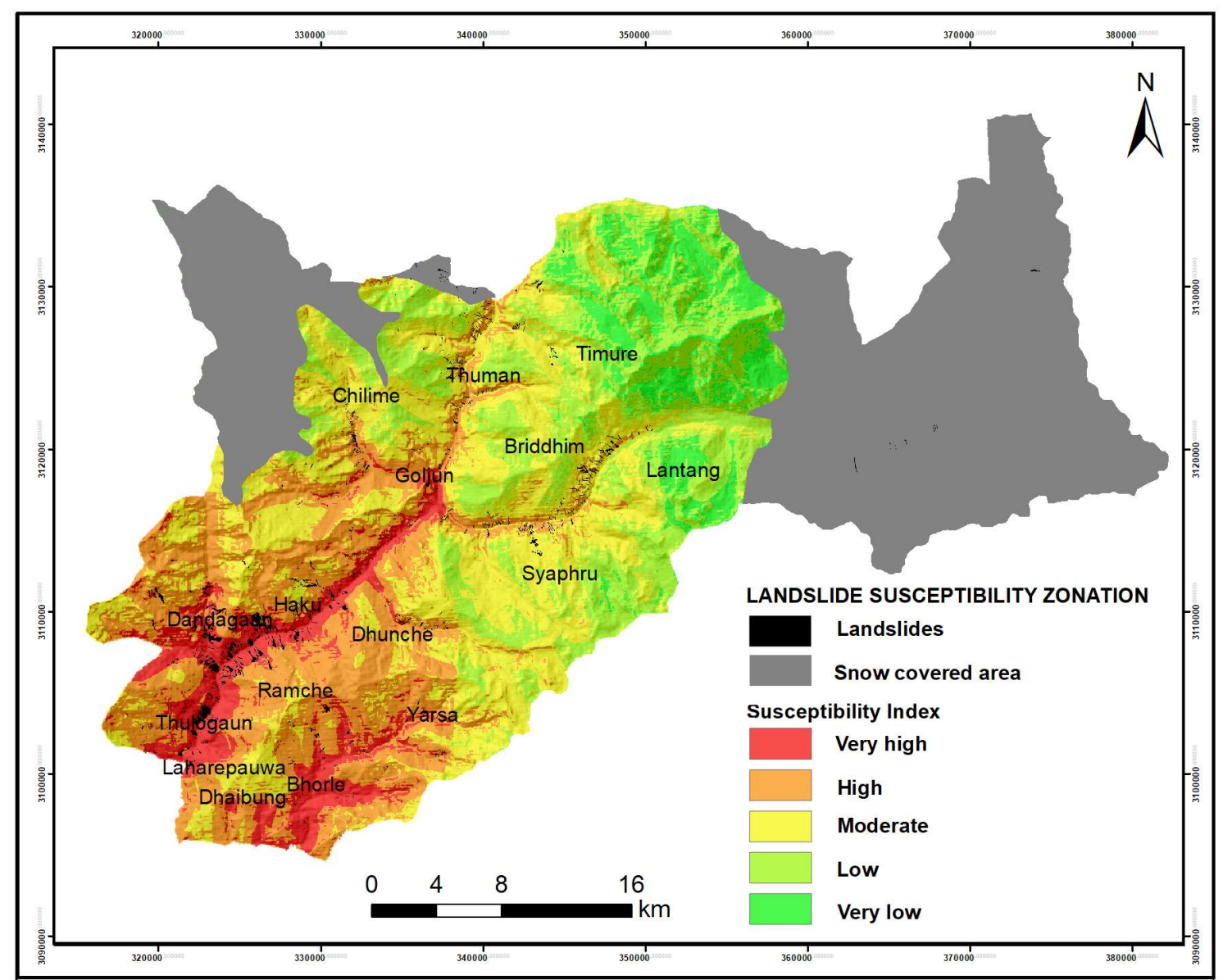

Fig. 5: Landslide susceptibility zonation map of the study area 


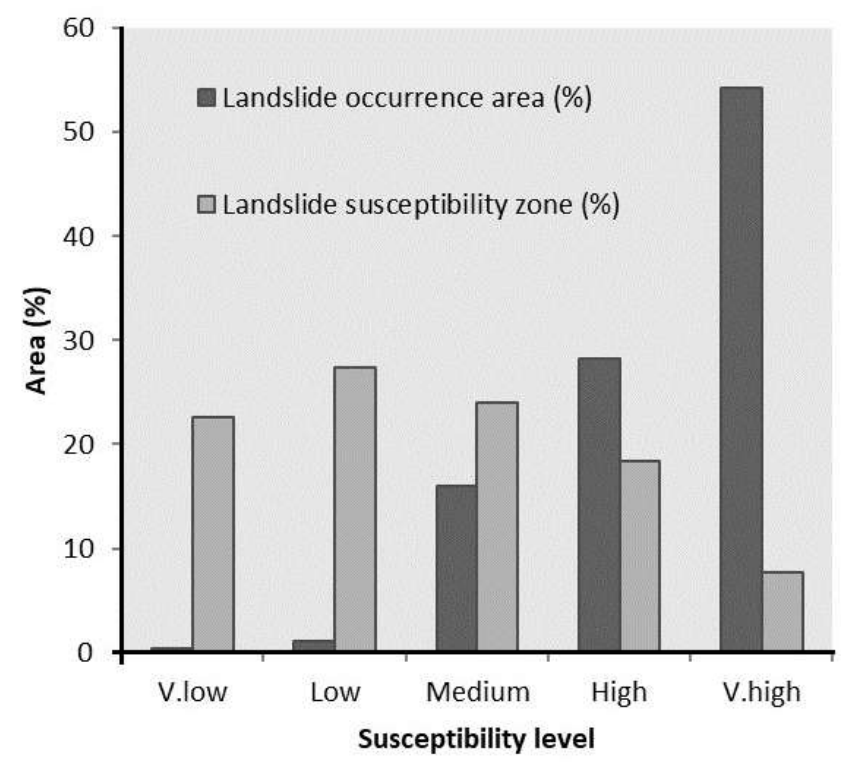

Fig. 6: Histogram showing relative distribution of landslides and susceptible zones.

LSM map is classified into five different zones using the natural breaks classification in GIS: very low, low, moderate, high and very high susceptibility zones (Fig. 5). A graph as performance model is prepared that indicated the highly susceptible area has maximum number of landslides and the distribution of landslides decreases with decrease in the susceptibility (Fig. 6). The higher value of PR indicates the stronger influence of the conditioning factor in occurrence of landslides. The northern part of the study area has low susceptibility towards landslides. The central and lower parts are likely to have more landslides. Geology comes out as the most influencing factor in landslide occurrence whereas slope aspect has the least influence. It is followed by elevation and drainage proximity. The analysis showed that the PGA has no direct impact on the Gorkha Earthquake triggered landslide which may be due to geological heterogeneity.

\section{DISCUSSION}

Geology $(\mathrm{PR}=2.52)$ and elevation $(\mathrm{PR}=2.38)$ are two most significant landslides occurrences controlling factors for the Rasuwa District, obtained from this study. The lithological control in landslide is due to the rock mechanics and weathering of rock formation (Kargel et al., 2016). The probability of landslide occurrence in the Ulleri Formation is high among all. This formation is comprised of augen gneiss with muscovite and biotite which are much weathered. In case of Nepal Himalayas, landslide distribution is high in gneiss, slate and phyllitic rock formations (Bhandary et al., 2013). Moreover, the landslides in the south-west part of study have occurred in the transition between the Ulleri and the Seti Formation containing the phyllites. The difference in the rock strength in this transition might be the next cause high impact of geology in the landslide occurrence.
The landslide distribution is high in the lower and moderate elevations. There is decrease in the landslide occurrence beyond the elevation of $2800 \mathrm{~m}$. This implies that higher elevation has no direct correlation with the landslides in this area. Drainage proximity is next parameter responsible for high probability of landslides with $\mathrm{PR}=2.12$. The landslide area lies in the intersection of drainage channel (Roback et al., 2017) and this indicates the drainage proximity has significant influence on occurrence of landslides.

The landslides are likely to occur in the steeper slopes. The frequency distribution of landslide is high beyond $30^{\circ}$. Generally, beyond this range rocks exceed their frictional strength and the natural state of consolidation is exceeded (Gnyawali and Adhikari, 2017). PGA and thrust, the dynamic variables, has less influence as compared to slope angle, elevation and geology. In case of Gorkha Earthquake, PGA was not spatially coincident and doesn't correlate directly (Roback et al., 2017). The area near to thrust are tectonically active which might be cause of landslides close to the thrust and decreasing pattern away from it. Landuse and slope aspect have very low influence among all factors. The combined effect of geology and topographic factors has played the major role in landslide occurrences.

\section{Validation}

Most susceptible areas for landslides are Haku, Dandagaun and Thulogaun region. The landslides are mostly distributed along the roadways and near to streams. Bhorle on the southern part has moderate susceptibility towards landslides while Timure has low susceptibility. AUC (Area Under Curve) is widely used accuracy statistics to predict the models in natural hazard assessment (Begueria, 2006) and the rate obtained can explain how well the model can predict the landslide (Chung and Fabbri, 1999). The landslide susceptibility map prepared using training dataset was validated using the testing data by preparing AUC. For obtaining the relative ranks, the calculated index value for each cell in study area is sorted in descending order (Pradhan and Lee, 2010). The ordered cell values are then divided into 100 classes which are set on y-axis, with accumulated intervals of $1 \%$ on $x$-axis. For training data, the rate verification line appears as given in Fig. 7a. The prediction rate of the model is given by testing data as in Fig. 7b. The success rate of $82.73 \%$ and prediction rate of $79.14 \%$ was obtained. $80-100 \%(20 \%)$ class of study area where the landslide hazard had higher rank could explain nearly $65 \%$ of all landslides in success rate and $55 \%$ of landslides in the prediction rate which is classified as very high susceptibility area.

\section{CONCLUSION}

The Rasuwa District landscape is vulnerable to landslides where $26.1 \%$ of the area has very high and high landslides susceptibility, $24 \%$ has moderate, $27.32 \%$ has low and $22.59 \%$ has very low landslides susceptibility. FR analysis gives highest value of prediction rate for geology (2.52) which makes it the 


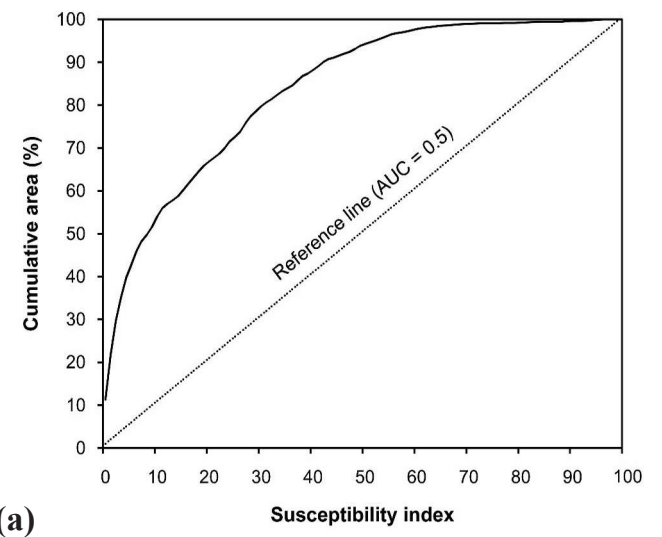

(a)

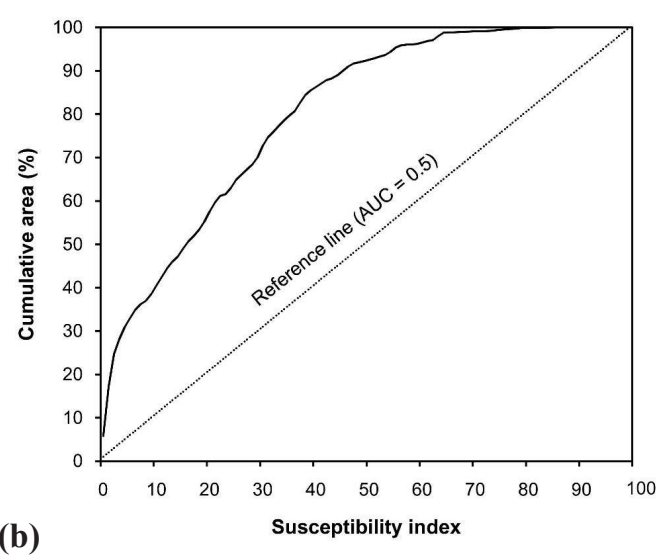

Fig. 7: AUC (a) for success rate calculated using training data, and (b) for prediction rate calculated using testing data

most influencing factor in occurrence of landslides followed by elevation (2.38) and drainage proximity (2.12). PGA (1.76) has anomalous effect on these earthquake-triggered landslides. The FR model performed well while in prediction where $82 \%$ of the total landslides happened to occur in very high and high susceptible zones. The success and prediction rate were $83.73 \%$ and $79.14 \%$ suggesting relevancy of the modeled landslide susceptibility within prediction accuracy of $50 \%$. However, the areas covered with snow have not been included in the analysis due to different characteristics of mass movements and mapping limitations therefore further analysis is recommended in this region. The prepared landslide susceptibility map can be helpful for landuse planning and landslide risk reduction measures in the Rasuwa District or in similar geo-environmental terrain.

\section{REFERENCES}

Acharya, G., De Smedt, F. and Long, N. T., 2006, Assessing landslide hazard in GIS: A case study from Rasuwa, Nepal. Bull. Eng. Geo. and Envir., v. 65(1), pp. 99-107.

Adhikari, L. B., Gautam, U. P., Koirala, B. P., Bhattarai, M., Kandel, T., Gupta, R. M., Timsina, C., Maharjan,N., Maharjan, K., Dahal, T., Hoste-Colomer, R., Cano, Y., Dandine, M., Guilhem, A., Merrer, S., Roudil, P. and
Bollinger, L., 2015, The aftershock sequence of the 2015 April 25 Gorkha-Nepal earthquake. Geophysical Supplements to the Monthly Notices of the Royal Astronomical Society, v. 203(3), pp. 2119-2124.

Althuwaynee, O. F., Pradhan, B., Park, H. and Lee, J. H., 2013, A novel ensemble bivariate statistical evidential belief function with knowledge-based analytical hierarchy process and multivariate statistical logistic regression for landslide susceptibility mapping. Catena, v. 114, pp. 21-36.

Begueria, S., 2006, Validation and evaluation of predictive models in hazard assessment and risk management. Nat. Hazards, v. 37(3), pp. 315-329.

Bhandary N. P., Yatabe R., Dahal R. K., Hasegawa S. and Inagaki, H., 2013, Areal distribution of large-scale landslides along highway corridors in central Nepal, Georisk: Assessment and Management of Risk for Engineered Systems and Geohazards. doi.org/10.1080/17499518.2012.743377.

Brabb, E. E., 1984, Innovative approaches to landslide hazard and risk mapping. In Proceedings of the 4th international symposium on landslides, Canadian Geotechnical Society, Toronto, v. 1, pp. 307-324.

Chawla, A., Chawla, S., Pasupuleti, S., Rao, A. C. S., Sarkar, K. and Dwivedi, R., 2018, Landslide Susceptibility Mapping in Darjeeling Himalayas, India. Advances in Civil Engineering, v. 2018, Article ID 6416492, 17 pages, 2018. https://doi.org/10.1155/2018/6416492.

Chung, C. F. and Fabbri, A. G., 1999, Probabilitstic prediction models for landslide hazard mapping. Photogrammetric Eng. Remote Sens., v. 65(12), pp. 1389-1399.

Collins, B. D. and Jibson, R. W. 2015, Assessment of existing and potential landslide hazards resulting from the April 25, 2015 Gorkha, Nepal earthquake sequence. U.S. Geol. Surv. Open-File Rept. 2015, v. 1142, 50 p.

Corominas, J., van Westen, C., Frattini, P., Cascini, L., Malet, J. P., Fotopoulou, S., Catani, F., van DenEeckhaut, M.,Mavrouli, O.,Agliardi, F.,EPitilakis, K., Winter, M.G., Pastor, M., Ferlisi, S., Tofani, V., Hervás, J., Smith, J.T., and Pitilakis, K., 2014, Recommendations for the quantitative analysis of landslide risk. Bull. Eng. Geol. \& Envir., v. 73(2), pp. 209-263.

Dai, F. C., Lee, C. F. and Xu, Z. W., 2001, Assessment of landslide susceptibility on the natural terrain of Lantau Island, Hong Kong. Envir. Geol., v. 40(3), pp. 381-391.

Dhital, M. R., 2015, Geology of the Nepal Himalaya: Regional Perspective of the Classic Collided Orogen (Regional Geology Reviews). Springer, 498 p.

Ercanoglu, M. and Gokceoglu, C., 2004, Use of fuzzy relations to produce landslide susceptibility map of a landslide prone area (West Black Sea Region, Turkey). Eng. Geol., v. 75, pp. 229-250.

Franks, C. A. M., 1999, Characteristics of some rainfall-induced 
landslides on natural slopes, Lantau Island, Hong Kong. The Quart. Jour. Eng. Geol. \& Hydrogeology, v. 32(3), pp. 247-259.

DMG, 2011 Geological Map published by Department of Mines and Geology (DMG). https://www.dmgnepal.gov.np/

Ghosh, S., Carranza, E. J. M., van Westen, C. J., Jetten, V. G. and Bhattacharya, D. N., 2011, Selecting and weighting spatial predictors for empirical modeling of landslide susceptibility in the Darjeeling Himalayas (India). Geomorphology, v. 131, pp. 35-56.

Gnyawali, K. R. and Adhikari, B. R., 2017, Spatial Relations of Earthquake Induced Landslides triggered by 25 April 2015 Gorkha Earthquake M=7.8. In: Mikos, M., Casagli, N., Yin, Y., and Sassa, L. (eds.) Advancing Culture of Living with Landslides. WLF 2017, pp. 85-93.

Gokceoglu, C. and Aksoy, H., 1996, Landslide susceptibility mapping of the slopes in the residual soils of the Mengen region (Turkey) by deterministic stability analyses and image processing techniques. Eng. Geol., v. 44, pp. $147-161$

Guzzetti, F., 2005, Landslide Hazard and Risk Assessment. PhD Thesis submitted to Mathematics-Scientific Faculty, University of Bonn, Bonn, Germany. 389 p.

Kargel, J. S., Leonard, G. J., Shugar, D. H., Haritashya, U. K., Bevington, A., Fielding, E. J., Fujita, K., Geertsema, M., Miles, E. S., Steiner, J., Anderson, E., Bajracharya, S., Bawden, G. W., Breashears, D. F., Byers, A., Collins, B., Dhital, M. R., Donnellan, A., Evans, T. L., Geai, M. L., Glasscoe, M. T., Green, D., Gurung, D. R., Heijenk R, Hilborn A, Hudnut, K., Huyck, C., Immerzeel, W. W., Liming, J., Jibson, R., Kääb, A., Khanal, N. R., Kirschbaum, D., Kraaijenbrink P. D. A., Lamsal, D., Shiyin, L., Mingyang, L. V., McKinney, D., Nahirnick, N. K., Zhuotong, N., Ojha, S-, Olsenholler, J., Painter, T. H., Pleasants, M. K. C., P., Yuan, Q., Raup, B. H., Regmi, D., Rounce, D. R., Sakai, A., Donghui, S., Shea, J. M., Shrestha, A. B., Shukla, A., Stumm, D., van der Kooij, M., Voss, K., Xin, W., Weihs, B., Wolfe D, Lizong, W., Xiaojun, Y., Yoder, M. R. and Young, N., 2016, Geomorphic and geologic controls of geohazards induced by Nepal's 2015 Gorkha earthquake. Science 351 (6269). DOI: $10.1126 /$ science.aac 8353

Komac, M., 2006, A landslide susceptibility model using the Analytical Hierarchy Process method and multivariate statistics in perialpine Slovenia. Geomorphology, v. 74, pp. $17-28$.

Lee, S., 2005, Application of logistic regression model and its validation for landslide susceptibility mapping using GIS and remote sensing data. Intern. Jour. Remote Sensing, v. 26(7), pp. 1477-1491.

Lee, S. and Dan, N. T., 2005, Probabilistic landslide susceptibility mapping in the Lai Chau province of Vietnam: focus on the relationship between tectonic fractures and landslides.
Environ. Geol., v. 48, pp. 778-787.

Lee, S. and Min, K., 2001, Statistical analysis of landslide susceptibility at Yongin, Korea. Environmental Geology, v. 40, pp. 1095-1113.

Lee, S., and Pradhan, B., 2006, Probabilistic landslide hazards and risk mapping on Penang Island, Malaysia. Jour. Earth Syst. Sci. v.115, pp. 661-672.

Lee, S. and Sambath, T., 2006, Landslide susceptibility mapping in the Damrei Romel area, Cambodia using frequency ratio and logistic regression models. Environmental Geology, v. 50, pp. 847-855.

Meena, S. R., 2017, Designing an approach for sustainable landslide inventory mapping in Nepal. Ph.D. Thesis, University of Twente, Netherlands, pp. 10-25.

National Seismological Centre (NSC), Kathmandu http://seismonepal.gov.np/earthquakes.

Nefeslioglu, H. A., Gokceoglu, C. and Sonmez, H., 2008, An assessment on the use of logistic regression and artificial neural netwoks with different sampling strategies for the preparation of landslide susceptibility maps. Eng. Geol., v. 97, pp. 171-191.

Pham, B. T., Tien-Bui, D., Prakash, I. and Dholakia, M., 2015, Landslide susceptibility assessment at a part of Uttarakhand Himalaya, India using GIS-based statistical approach of frequency ratio method. Intern. Jour. Eng. Res \& Tech., v. 4, pp. 338-344.

Pradhan, B. and Lee, S., 2010, Landslide susceptibility assessment and factor effect analysis: Backpropagation artificial neural networks and their comparison with frequency ratio and bivariate logistic regression modelling. Environ. Model, Software, v. 25, pp. 747-759.

Regmi, A. D., Dhital, M. R., Zhang, J. Q., Su, L. J., and Chen X. Q., 2016, Landslide susceptibility assessment of the region affected by the 25 April 2015 Gorkha earthquake of Nepal. Jour. Mount. Sci. v. 11, pp. 941-1957

Roback, K., Clark, M. K., West, A. J., Zekkos, D., Li, G., Gallen, S. F., Chamlagain, D. and Godt, J. W., 2017, The size, distribution, and mobility of landslides caused by the 2015 Mw 7.8 Gorkha earthquake, Nepal. Geomorphology, pp. 121-138.

Saha, A. K., Gupta, R. P. and Arora, M. K., 2002, GIS-based landslide hazard zonation in the Bhagirathi (Ganga) valley, Himalayas. Intern. Jour. Remote Sensing, v. 23(2), pp. 357-369.

Shrestha, A. B., Bajracharya, S. R., Kargel, J. S. and Khanal, N. R., 2016, The impact of Nepal's 2015 Gorkha earthquake-induced geohazards. ICIMOD Research Report 2016/1. Kathmandu, ICIMOD.

Shrestha, S., Kang, T. and Suwal, M., 2017, An Ensemble Model for Co-Seismic Landslide Susceptibility Using GIS and Random Forest Method. ISPRS Intern. Jour. Geo- 
Information, v. 6, pp. 365.

Tsapanos, T. M., 2003, Appraisal of seismic hazard parameters for the seismic regions of the east circum-Pacific belt inferred from a Bayesian approach. Nat. Hazards, v. 30, pp. 59-78.

USGS, 2004, Landslide Types and Processes. United States Geological Survey (USGS) [On-line]. Available: http://pubs.usgs.gov/fs/2004/3072/fs-2004-3072.html
Xu, C., Tian, Y., Zhou, B., Ran, H., and Lyu, G., 2017, Landslide damage along Araniko highway and Pasang Lhamu highway and regional assessment of landslide hazard related to the Gorkha, Nepal earthquake of 25 April 2015. Geoenvironmental Disasters. v. 4, pp. 14.

Yalcin, A., 2005, An investigation on Ardesen (Rize) region on the basis of landslide susceptibility. Ph.D. Thesis, Karadeniz Technical University, Trabzon, Turkey (In Turkish). 